

\section{GLOBAL CLIMATE}

All major greenhouse gases released into Earth's atmosphere reached new record high concentrations in 2019. The annual global average carbon dioxide concentration at Earth's surface was $409.8 \pm 0.1 \mathrm{ppm}$, an increase of $2.5 \pm 0.1 \mathrm{ppm}$ over 2018, and the highest in the modern instrumental record and in ice core records dating back 800000 years. Greenhouse gases, along with several halogenated gases, have contributed to a $45 \%$ increase in net forcing compared to 1990. Carbon dioxide is responsible for nearly two-thirds of this increase.

A weak El Niño early in the year transitioned to ENSO-neutral conditions by mid-year, yet the annual global surface temperature across land and ocean surfaces was still among the three highest on record. July became the hottest month in records dating to the mid- to late-1800s. Each decade since 1980 is warmer than its preceding decade, with 2010-19 being around $0.2^{\circ} \mathrm{C}$ warmer than $2000-09$.

In 2019, there were a record high number of extreme warm days (temperatures above the 90th percentile) over global land surfaces. There were also a low number of extreme cool days (temperatures below the 10th percentile) compared to the last 70 years, but there were more cool days compared to the average of just the past decade. A new indicator introduced this year to the report-marine heat waves-indicates that the number of strong marine heatwaves surpassed the number of more moderate marine heat waves for the sixth consecutive year. Lake temperatures increased on average across the globe in 2019; observed Northern Hemisphere lakes were covered in ice seven days fewer than the 1981-2010 average, according to phenological records. Over land, the growing season was an average of eight days longer than the 2000-10 average in the Northern Hemisphere. In colder regions, alpine glaciers around the world continued to lose mass for the 32nd consecutive year, while record high permafrost temperatures were observed at many observing sites across the high northern latitudes.

Total precipitation across global land areas was below the 1981-2000 average and also less than measured in 2018. As is always the case, there was substantial variability across the planet in 2019. Several noteworthy events are highlighted in the following Regional Climate sections.

Above Earth's surface, the annual lower troposphere temperature was third highest to record high, and the lower stratosphere temperature was third lowest to record low, depending on the dataset analyzed. Toward the end of the year, the Raikoke (Russia) and Ulawun (Papua New Guinea) volcanic eruptions and large Australian wildfires loaded the stratosphere with aerosol levels unprecedented since the post-Mt. Pinatubo era began 25 years ago.

\section{GLOBAL OCEANS}

In 2019, global mean sea level set a new record for the eighth consecutive year, an increase of $6.1 \mathrm{~mm}$ from 2018. Record high ocean heat content measured to $700 \mathrm{~m}$ depth in 2019 contributed an estimated $4.5 \mathrm{~mm}$ of that rise. Since 2004, ocean heat content has been increasing at a rate exceeding $0.20^{\circ} \mathrm{C}$ per decade near the surface and at a lower but still increasing rate of less than $0.03^{\circ} \mathrm{C}$ decade in deeper waters below $300 \mathrm{~m}$. The annual 
(a) Europe

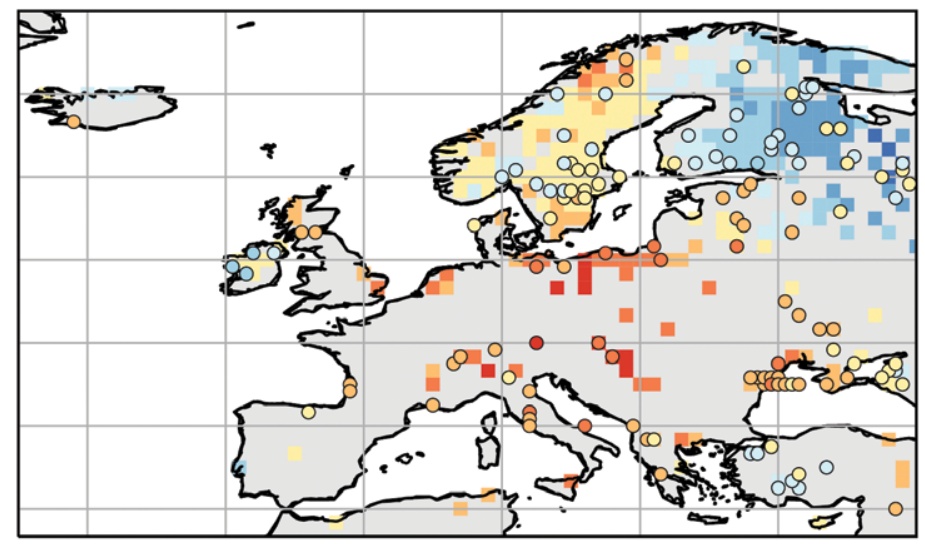

(c) Canada

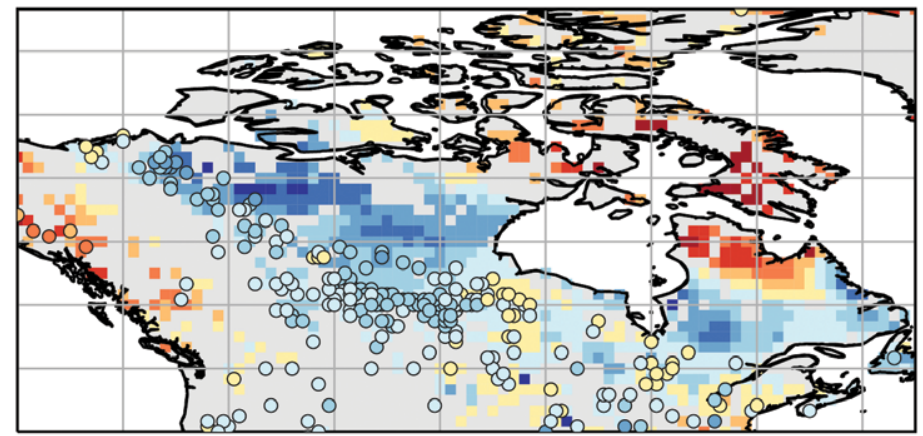

(b) Africa

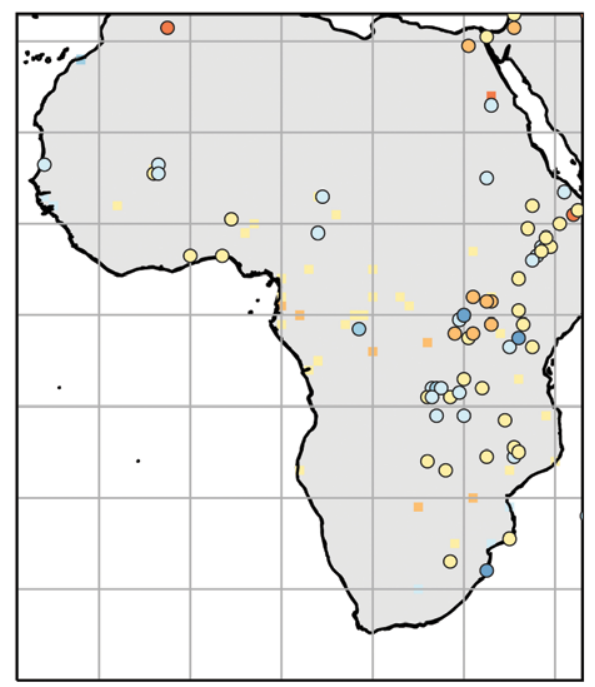

(d) Tibetan Plateau

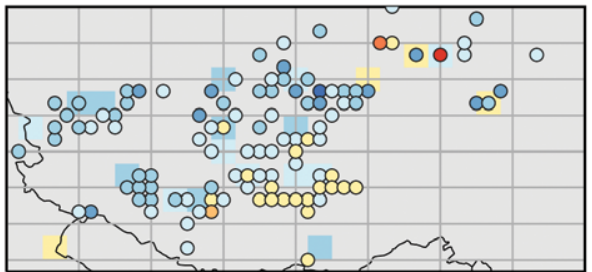

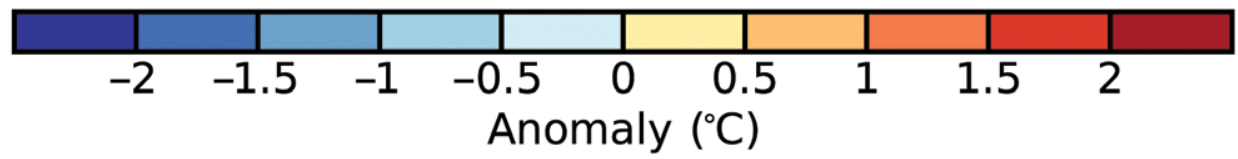

Lake temperature anomalies for 2019, compared to the 1996-2015 average, broadly reflected large-scale air temperature patterns, and associated timing of the melting of lake ice cover, during the year. European and Alaskan lakes, on average, experienced one of the warmest years of the last quarter century, continuing a warming trend over that same period. Canadian lakes were quite cool compared to twenty-first century norms, and in contrast to their long-term warming trend. Lakes in Africa and the Tibetan Plateau have shown more neutral trends since the late twentieth century, and they were near average and cooler than average during 2019, respectively. (Fig. 2.3 in State of the Climate in 2019; see discussion there in section 2b2, and related lake ice cover conditions in Sidebar 2.1.)

globally averaged sea surface temperature was the second highest on record, surpassed only by the record El Niño year of 2016.

The ocean had a net uptake of about 2.4 billion metric tons of carbon dioxide in 2019. This is a record high amount and an increase of 0.2 billion metric tons from 2018, continuing a trend that began at the start of the twenty-first century. As a consequence of increased carbon dioxide in the ocean, surface ocean $\mathrm{pH}$ has declined by $0.018 \pm 0.004$ units per decade in most of the ocean, making it more acidic, since the pre-industrial period. This is particularly notable in colder waters.
The Indian Ocean dipole, which is the difference in sea surface temperatures between the western and eastern Indian Ocean, reached a historic high positive value in October 2019, associated with dramatic upper ocean warming in the western Indian Ocean basin. This difference resulted in more precipitation in the west and drier conditions in the east in 2019, which led to fresh waters in the west and salty surface waters in the east. In the North Pacific Ocean, sea surface temperatures increased significantly in the latter half of the year, leading to the reemergence of a "warm blob" that was also related to a decrease in precipitation. 
Fresher- and saltier-than-normal surface waters across the global oceans

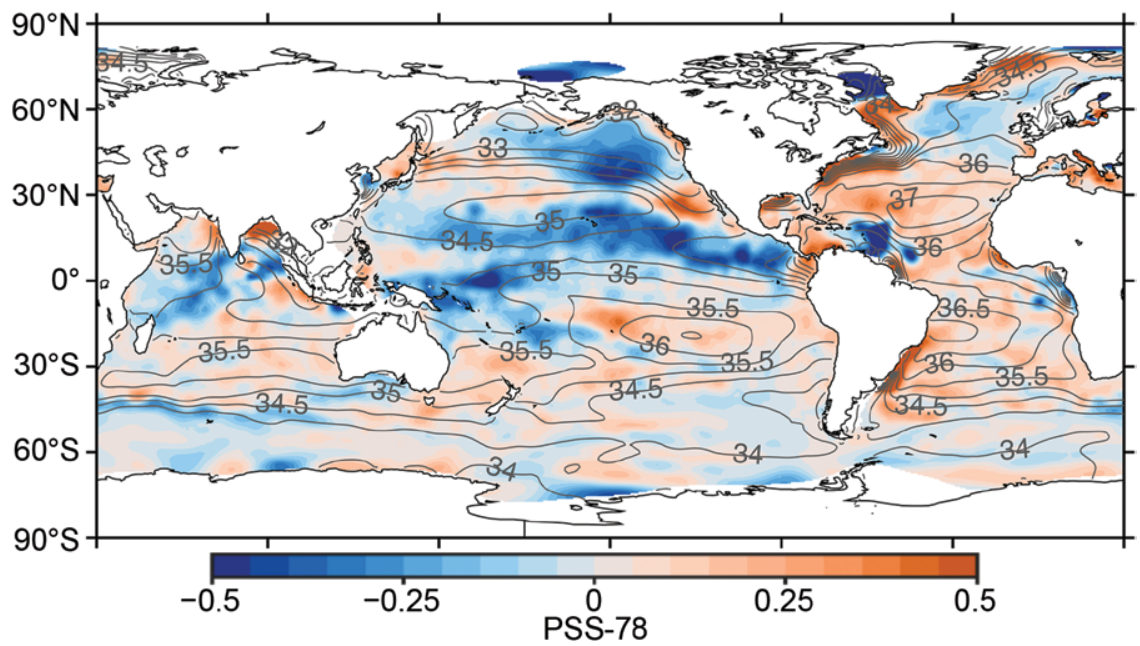

Surface salinity anomalies for 2019, compared to the 1955-2012 monthly salinity fields, reflect conditions specific to the year and, because salinity patterns tend to be long-lived, of recent years. The Pacific was largely fresher (blue) than normal during 2019, and the Atlantic quite salty (red), each reflecting a continuation of trends in recent years. The strongly positive Indian Ocean dipole, which affected many parts of the climate system during 2019, is apparent in that basin's salinity anomalies. The western Indian Ocean, which saw significantly above average precipitation, is quite fresh, while the eastern basin, which was quite dry, is anomalously salty. Strong 2019 pluvial conditions and enhanced runoff across northern South America enhanced existing fresher-than-normal plumes emanating from the Amazon and Orinoco Rivers into the tropical North Atlantic. Finally, subtropical belts, which are naturally saltier due to an evaporation-dominant basic climate, were generally even saltier than average in 2019, while more tropical and typically fresh regions were even fresher. This reflects a persistent twenty-first century trend that reflects an intensification of the hydrologic cycle over the oceans. (Fig. 3.7a in State of the Climate in 2019; see discussion there in section 3d2.)
In total, 96 named tropical cyclones were observed during the combined Northern Hemisphere and Southern Hemisphere storm seasons, well above the 19812010 average of 82 . Five tropical cyclones across the globe reached Saffir-Simpson Hurricane Wind Scale Category 5 intensity levelDorian and Lorenzo in the North Atlantic, and Wutip, Hagibis, and Halong in the western North Pacific-well below the all-time record of 12 such storms in 1997 and 11 in 2018.

The Accumulated Cyclone Energy index-a measure of the total of each individual storm's wind energy throughout its lifewas above average in each tropical cyclone basin in the Northern Hemisphere. It was the highest on record for the North Indian Ocean, nearly double the previous records in 2007 and 2013 and more than four times higher than the 1981-2010 average.

\section{THE ARCTIC}

The Arctic land surface temperature for 2019 was the second highest in the 120-year record, following 2016, with record high temperatures in Alaska and northwest Canada. Mean annual Arctic

\section{THE TROPICS}

The annual average temperature across land and ocean surface between $20^{\circ} \mathrm{N}$ and $20^{\circ} \mathrm{S}$ was $+0.47^{\circ} \mathrm{C}$ above the $1981-2010$ average, making 2019 the third-warmest year for the tropics since records began in 1880, and the warmest since 2016.

Across the central and eastern equatorial Pacific Ocean, a weak El Niño at the beginning of 2019 transitioned to ENSO-neutral by July, which prevailed for the remainder of the year. While ENSO conditions during 2019 appeared to have limited impacts, many climate events were influenced by the strong positive Indian Ocean dipole, which, in October, reached its greatest magnitude since 1997. The precipitation patterns resulting from the event, as described in the Global Oceans section above, contributed to a large rainfall deficit from the eastern Indian Ocean to the South Pacific Ocean east of Australia. This strong positive Indian Ocean dipole was unique in that it was not associated with concurrent strong El Niño conditions, as is typical. surface air temperatures over land have increased more than twice as fast as the global mean since the mid-1980s.

In March 2019, when Arctic sea ice reached its maximum extent for the year, thin, first-year ice predominated at $\sim 77 \%$ of the footprint's area, compared to about $55 \%$ in the 1980s. Winter sea ice coverage in the Bering Sea was by far the lowest since at least 1850, the second year in row to break the record low. In September, the minimum sea ice extent at the end of summer tied with 2007 and 2016 for the second smallest in the 41-year satellite record.

During the 2019 melt season, the extent and magnitude of ice loss over the Greenland ice sheet rivaled 2012, the previous year of record ice loss. Glaciers and ice caps across the Arctic also continued a trend of significant ice loss throughout the Arctic, especially in Alaska and Arctic Canada. The Greenland ice sheet and the Arctic-wide mass loss from glaciers and ice caps outside of Greenland are estimated to contribute approximately 0.7 and $0.4 \mathrm{~mm} \mathrm{yr}^{-1}$, respectively, to global sea level rise. 
Shifting fish populations in the Bering Sea as ocean temperatures increase
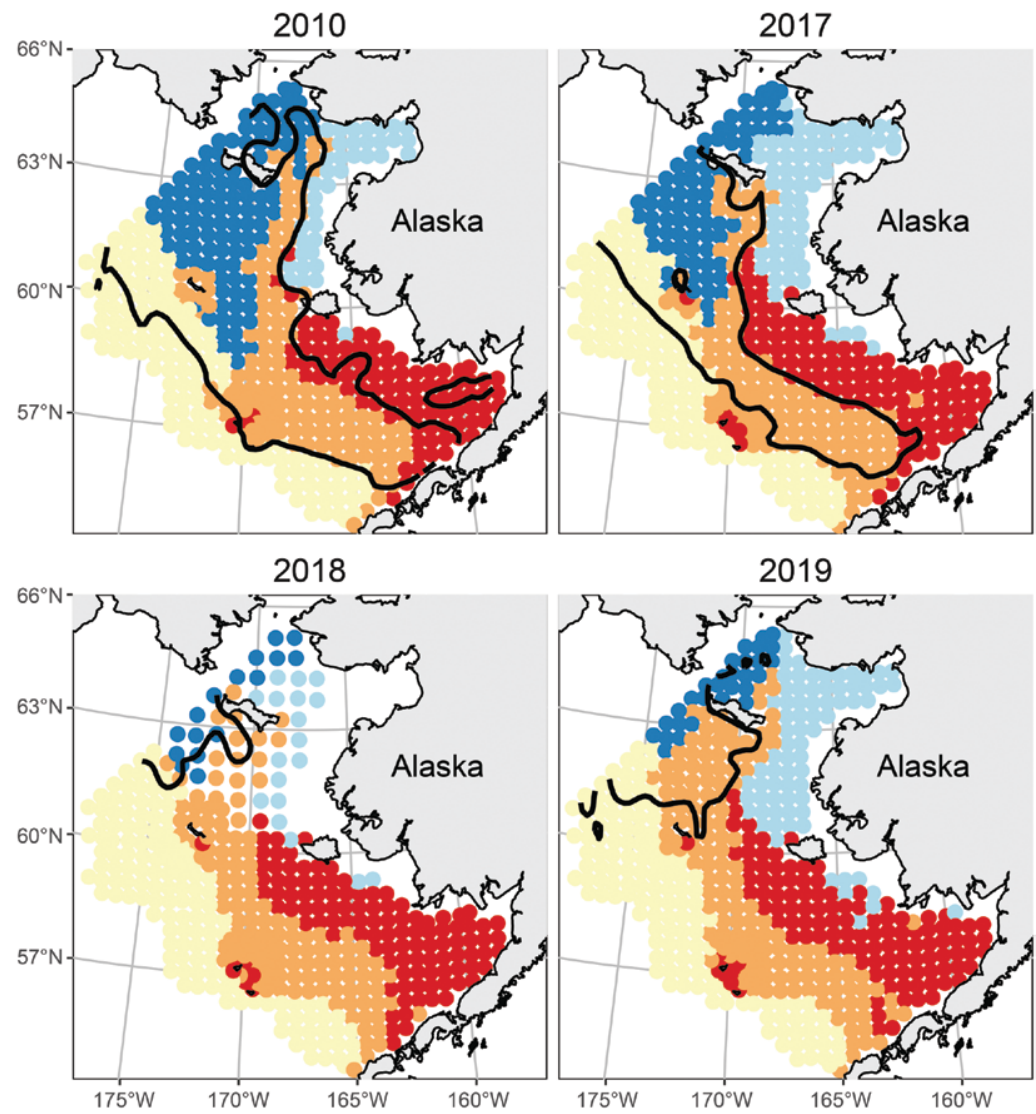

In the Bering Sea, increasing ocean temperatures and reduced sea ice-which was the lowest on record there for the second consecutive winter-are leading to shifts in fish distributions within some of the most valuable fisheries in the world. Larger and more abundant boreal species (for example, Pacific cod), as opposed to smaller and less abundant Arctic species (for example, Arctic cod), began dominating a large portion of the shelf in 2018 and 2019. (Fig. SB5.1 in State of the Climate in 2019; see discussion there in Sidebar 5.1) interactions between the ocean and the ice sheet, with the highest rates of mass loss occurring in West Antarctica and Wilkes Land, East Antarctica.

In the oceans surrounding the continent, warm surface conditions prevailed in 2019, and a record amount of more heat was absorbed into the ocean south of $35^{\circ} \mathrm{S}$ than was released. Below-average sea ice extent persisted throughout the year. This continues a trend that began in September 2016. During 2019, record low monthly mean sea ice extent was recorded in both January and June. There were 11 days in January during which sea ice area-the actual area covered by sea ice-was the lowest on record.

In the atmosphere above Antarctica, tropospheric waves that propagated upward in late August resulted in record-setting stratospheric temperatures as high as $16^{\circ} \mathrm{C}$ above average at $50 \mathrm{hPa}$ in early September. This sudden stratospheric warming event strongly affected climate trends for the remainder of the year and led to the smallest ozone hole since the early 1980 s.

\section{REGIONAL CLIMATES}

North America. Annual temperatures were above the 1981-2010 average across most of Canada north of $60^{\circ} \mathrm{N}$ and below average over most of Canada south of $60^{\circ} \mathrm{N}$. Alaska was record warm, while the contiguous United States observed its coolest year since 2014, while still ranking in the warmest third of the 125-
In 2019, record high permafrost temperatures were observed at a majority of the observation sites, with temperatures in northern Alaska $0.1^{\circ}-0.2^{\circ} \mathrm{C}$ higher than in 2018. In all regions, the average active layer thickness-the amount of ground above the permafrost layer-in 2019 was above the mean value for the 10-year reference period 2003-12. As a result of long-term permafrost warming and relatively mild and snowy winters in 2017/18 and 2018/19, the active layer did not freeze completely at 26 sites in interior Alaska and the Seward Peninsula for the first time in the observation record.

\section{ANTARCTICA AND}

\section{THE SOUTHERN OCEAN}

The Antarctic continent observed its second-warmest year, behind 1980 , since the start of the reanalysis record in 1979 , at $0.55^{\circ} \mathrm{C}$ above the $1981-2010$ average. The Antarctic ice sheet continued to lose mass, mainly due to year historical record. Mexico reported its second-warmest year, tying with 2016 and cooler only than 2017, with August marking the warmest month of any month in the country's 67-year record.

The contiguous United States had its second-wettest year on record, behind 1973. Winter (December-February 2018/19) precipitation was a record $134 \%$ of average. The abundant precipitation early in the year, especially over drought-stricken areas in the West, helped improve conditions, bringing the national drought footprint to its minimum extent of approximately 2\% in April.

Canada experienced a catastrophic spring flood along the Ottawa and St. Lawrence Rivers, with record-breaking discharge. This was even larger than an event that occurred in 2017, considered at the time to be the flood of the century. During late April, mild temperatures and significant rains combined to rapidly melt the snowpack 
in New Brunswick. The Saint John River at the Maine-New Brunswick border had its largest peak streamflow in 67 years. Farther downstream, the peak river level in Fredericton was over $8.3 \mathrm{~m}$, the second-highest level on record (behind 1973). As a result, more than 5500 dwellings were flooded or at risk, and over $400 \mathrm{~km}^{2}$ of land were flooded. In the United States, heavy and frequent precipitation and rapid snowmelt contributed to extensive flooding in the Midwest throughout spring and summer, notably in the Mississippi and Missouri basins.

Nearly 50000 wildfires were recorded across the contiguous United States in 2019, which was the second-lowest number recorded in the 20-year record; only 2013 had fewer wildfires. The 2019 fires consumed approximately 4.6 million acres,
Rare stratopheric warming event in the Southern Hemisphere

$\Delta$ Temperature $\left(90^{\circ} \mathrm{S}\right)$

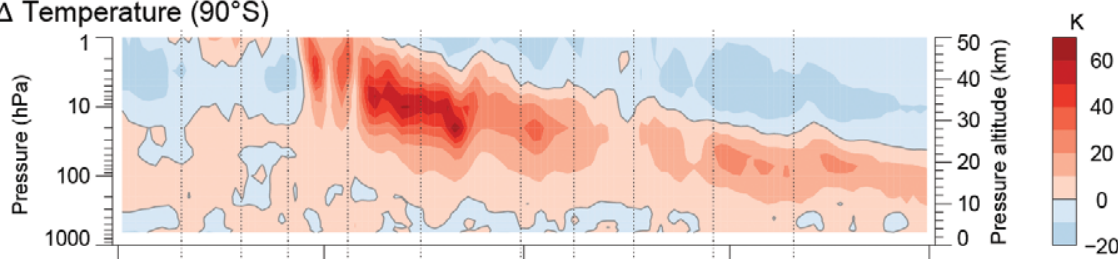

$\Delta$ Ozone $\left(70^{\circ}-90^{\circ} \mathrm{S}\right)$

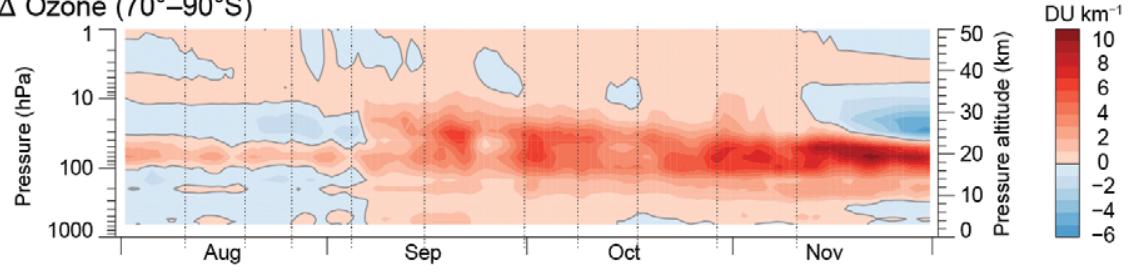

While major stratospheric warming events occur several times per decade in the polar Northern Hemisphere, they are quite rare in the Southern Hemisphere. A significant event occurred during late 2019, peaking in September and October, when the westerly momentum of the southern polar vortex was disrupted and eroded by a series of planetary-scale wave events that propagated from the troposphere beginning in early August. The warming associated with this series of waves led to significantly higher-than-average stratospheric ozone concentrations below $10 \mathrm{hPa}$, resulting in the smallest Antarctic ozone hole since the early 1980s. (Figs. SB6.1c,d in State of the Climate in 2019; see discussion there in Sidebar 6.1)

\section{Billion dollar disasters in the United States}

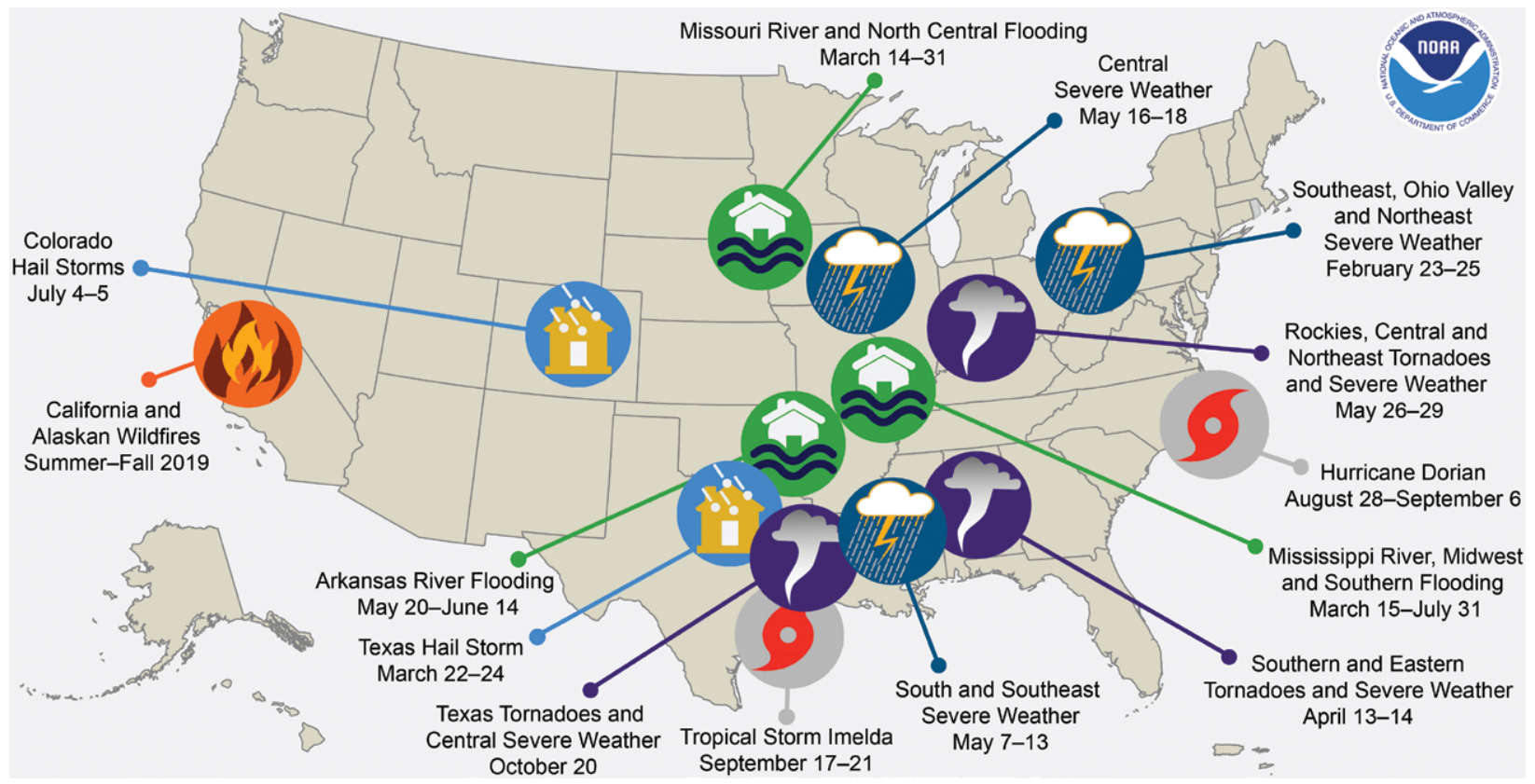

There were 14 weather and climate events during 2019 with losses each exceeding \$1 billion (U.S. dollars) across the United States and totaling 44 fatalities: three inland flooding events, eight severe storm events, two tropical cyclone events (Dorian and Imelda), and one wildfire event. The year's loss total of $\$ 45.0$ billion (U.S. dollars) was above the 1980-2019 annual cost average, adjusted for inflation, of \$43.9 billion (U.S. dollars). (Fig. 7.5 in State of the Climate in 2019; see discussion there in section 7b2) 
which was the sixth-smallest area burned in the last 20 years.

For a third consecutive year, drought conditions worsened in southern Mexico due to the absence of tropical cyclones near this region. Adverse impacts for the region included water shortages in the states of Veracruz and Tabasco, a lack of pasture forage and water supplies, and reduced runoff in streams, which was exacerbated by high temperatures.

Central America and the Caribbean. During 2019, much of Central America had near- to above-normal temperatures and near- to below-normal precipitation. The average temperature anomaly over the Caribbean was approximately $+0.81^{\circ} \mathrm{C}$ higher than the 1981-2010 average, making 2019 the warmest year for the region since records began in 1891.

Short- and long-term drought conditions were observed across several Caribbean islands during the year related to the weak El Niño event during the first half of 2019.
March 2019 was the driest March since 1951 in Saint Croix (0.5 mm), contributing to its fourth-driest year on record. June-December was generally dry and warm, with heat waves reported in most locations. From August to October, warming ocean waters necessitated Level 1 (bleaching expected) and Level 2 (widespread bleaching and some mortality expected) coral bleaching heat stress alerts for the region.

Tropical Storm Karen caused flooding and storm surges in parts of the southeastern and northeastern Caribbean, impacting Trinidad and Tobago, Dominica, Puerto Rico, and other islands. The storm impacted Puerto Rico the day after the island experienced a 6.0 earthquake on the Richter scale. The combined effects resulted in destruction of infrastructure, landslides, flooding, and the closure of government offices and schools.

On 23 October, a tropical depression developed near Belize, intensifying over the Gulf of Mexico to become Tropical Storm Olga. In the eastern tropical Pacific, no tropical storms made landfall on Central America.

\section{Hurricane Dorian storm track}

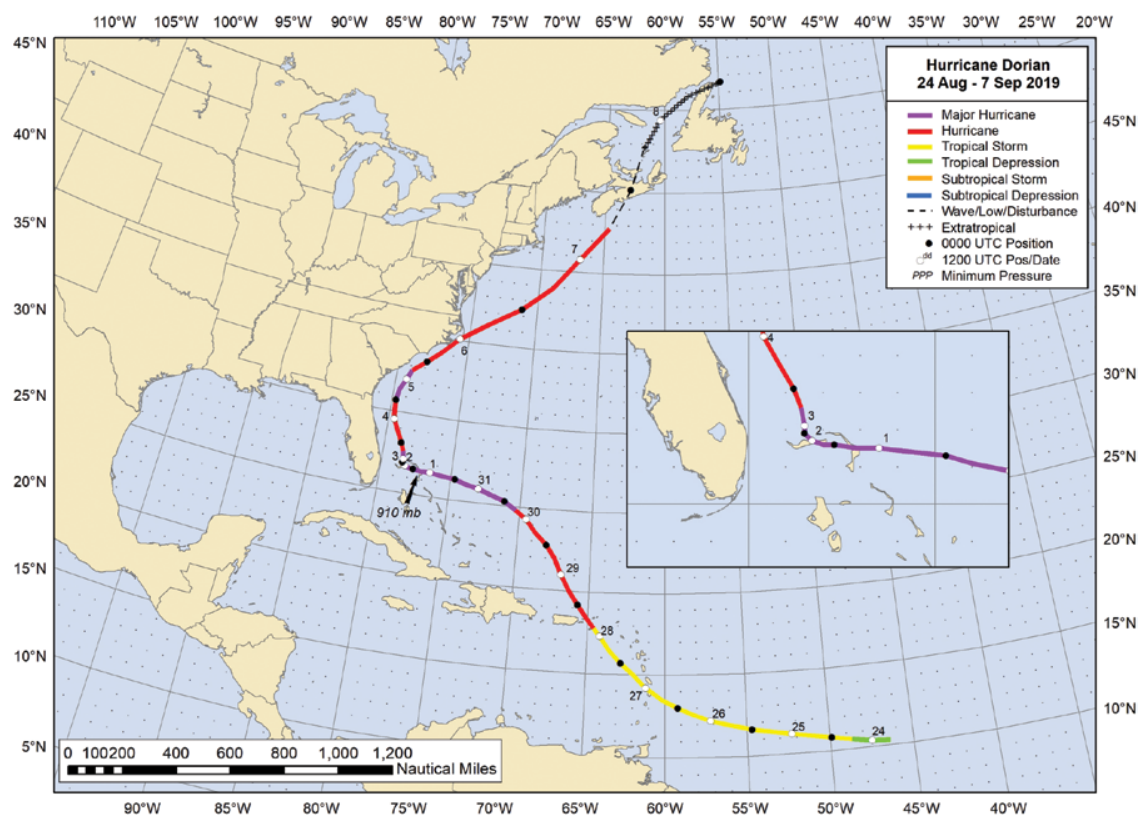

Category 5 Major Hurricane Dorian caused unprecedented and tremendous devastation to The Bahamas, particularly on the Abaco Islands and on Grand Bahama Island. Dorian reached its maximum intensity of $\mathbf{1 6 0} \mathbf{~ k t}$ as it made landfall on Great Abaco Island on 1 September, becoming the strongest hurricane on record to make landfall in The Bahamas and tying with the Labor Day Hurricane of 1935 for the strongest landfalling hurricane on record anywhere in the Atlantic basin. Approximately 70 fatalities were reported in this region and over $\$ 3.4$ billion (U.S. dollars) in damages were generated. Dorian was also responsible for six fatalities in Florida and three in North Carolina and caused over \$1 billion (U.S. dollars) in damages in the United States. As a post-tropical cyclone, Dorian also caused considerable damages in Nova Scotia, Canada, with over $\mathbf{\$ 1 0 0}$ million (U.S. dollars) in damages. (Fig. SB4.1 in State of the Climate in 2019; see discussion there in section $4 \mathrm{f6}$ and Sidebar 4.1)
South America. South America as a whole observed its secondwarmest year on record at $+0.69^{\circ} \mathrm{C}$ above the 1981-2010 normal, behind only 2015. The last five years were the five warmest years in the continent's 110-year record.

Mean temperatures in January were $1.5^{\circ}-2.5^{\circ} \mathrm{C}$ above normal in southeastern Bolivia and Paraguay, while the northern coast of Peru and tropical Brazil had temperatures $2.0^{\circ}-5.0^{\circ} \mathrm{C}$ above normal. At the end of January, several locations in south central South America observed new daily maximum temperature records that surpassed their previous records by $5.0^{\circ}-8.0^{\circ} \mathrm{C}$. During 25-28 January, the northern coast of Peru experienced its most intense heat wave of the last 30 years. Paraguay observed its hottest days on record on 23-24 January, when maximum temperatures soared to $39.4^{\circ}-43.0^{\circ} \mathrm{C}$.

Several episodes of extreme warm temperatures in southern South America occurred during the season, with the most significant episode occurring in February. Near the southern tip of Argentina, the maximum temperature in Río 
Grande, Tierra del Fuego, rose to $30.8^{\circ} \mathrm{C}$ on 4 February, marking the first time on record a temperature above $30^{\circ} \mathrm{C}$ was recorded so far south in South America.

Very dry conditions affected parts of northern South America early in the year, with several locations experiencing drought. The drought conditions contributed to a large number of forest fires in Venezuela, especially during February and March. Water shortages were reported at nearly $10 \%$ of Colombia's municipalities during the first three months of the year. In Guyana, drought in the region of Rupununi and Barima-Waini caused a sugar cane yield loss of $35 \%$, water scarcity for human consumption and irrigation, and forest fires.

Conversely, the Atlantic Intertropical Convergence Zone was active in March, producing intense rainfall in northeast Brazil. After seven years of drought, the semiarid region of northeast Brazil recorded near-normal rainfall from November 2018 to April 2019. Hydrological deficits, however, persisted across most of the region.

In south-central Chile, rainfall deficits in 2019 added to a prolonged drought that began there in 2010. The cities of Valparaiso and Curicó (Chile) and Bahía Blanca (Argentina) had their driest year on record since 1961. Santiago, Chile's capital, observed its third-driest year since records began in 1866 .

Wildfires scorched vast areas of the southern Amazon region and northern Paraguay in 2019. The number of fires detected in the Brazilian Amazon region was 89178 in 2019, compared to 68345 fires in 2018. Fires also affected 6.4 million hectares in Bolivia in 2019, significantly above the yearly average of 3.5 million hectares.
Africa. The year 2019 was the warmest year on record for South Africa (tied with 2015) as well as for several western Indian Ocean island countries, including Mauritius, Mayotte, Comoros, Seychelles, and Réunion Island. Six record warm months throughout the year and a new all-time high daily maximum temperature of $37.0^{\circ} \mathrm{C}$ at Pointe des Trois-Bassins on 25 January contributed to Réunion's annual warmth. In northern Africa, record high temperatures of $47^{\circ} \mathrm{C}$ were recorded in Egypt in June. More record temperatures, ranging from $43.5^{\circ}-50^{\circ} \mathrm{C}$, were reported at several stations in Algeria during July.

A strong positive Indian Ocean dipole contributed to excess rainfall in the Horn of Africa from October through December that resulted in widespread flooding across East Africa. Mombasa (Kenya) received more than five times its normal October rainfall, as did Kinshasa and Pt. Noire in the Republic of Congo. A combination of heavy rainfall, moist soil conditions, abundant vegetation, and dominant northerly/northeasterly persistent winds led to a widespread locust invasion from Eritrea southward through eastern Ethiopia, Kenya, and Sudan to Somalia. This infestation led to extensive crop and vegetation damage over the region.

Seychelles observed its second-wettest year in its 47-year record, behind 1997, and the Comoros archipelago, particularly Grande Comore, also recorded one of its wettest years on record. To the southeast, Réunion Island observed its driest rainy season (December-April) on record. Dry conditions persisted over large parts of western South Africa, in some areas continuing a seven-year trend.

\section{Evolving monthly drought conditions across Brazil in 2019}

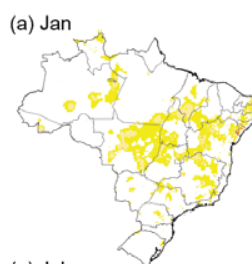

(g) Jul

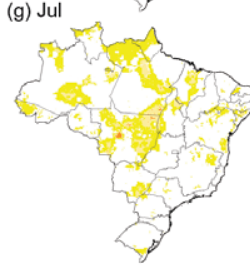

(h) Aug

(b) Feb
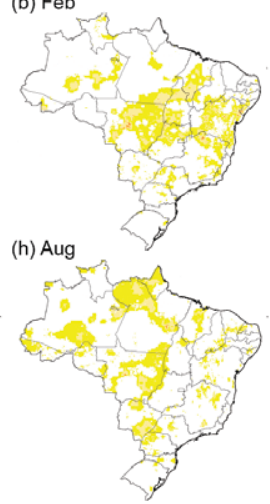

(c) Mar

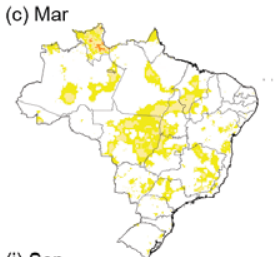

(i) Sep

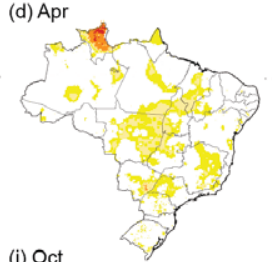

(j) Oct
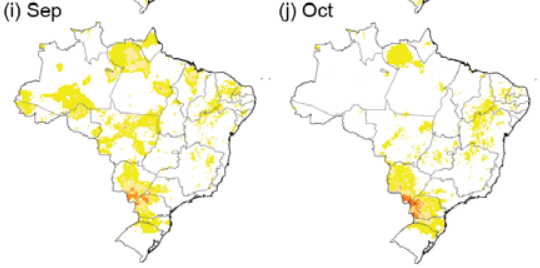

(e) May

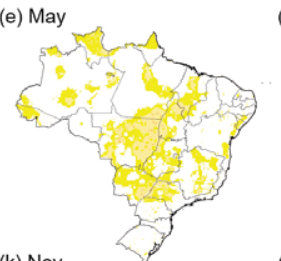

(k) Nov

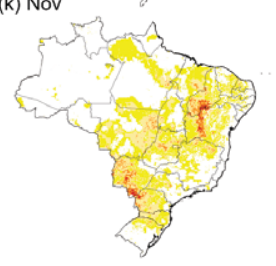

Dry

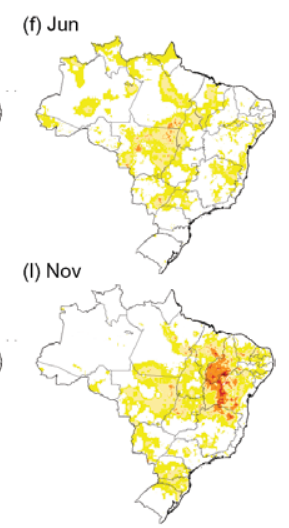

(f) Jun

None

Drought

Weak to moderate drought was present during January-March in the southern Brazilian Amazonia, associated with below-average precipitation related to the weak El Niño event. Rainfall deficits during the summertime peak of the rainy season may have contributed to the fires during the winter season. While no human fatalities were reported, these fires affected biodiversity, fauna, and flora, and generated negative impacts on the Amazon biome. (Fig. SB7.4 in State of the Climate in 2019; see discussion there in Sidebar 7.2) 


\section{Hurricanes Idai and Kenneth storm tracks}

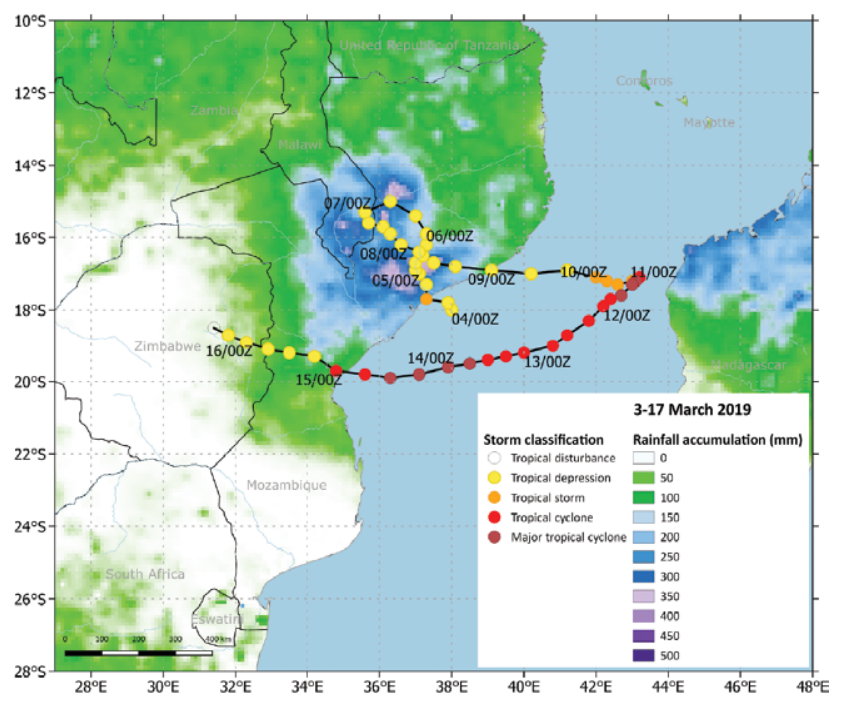

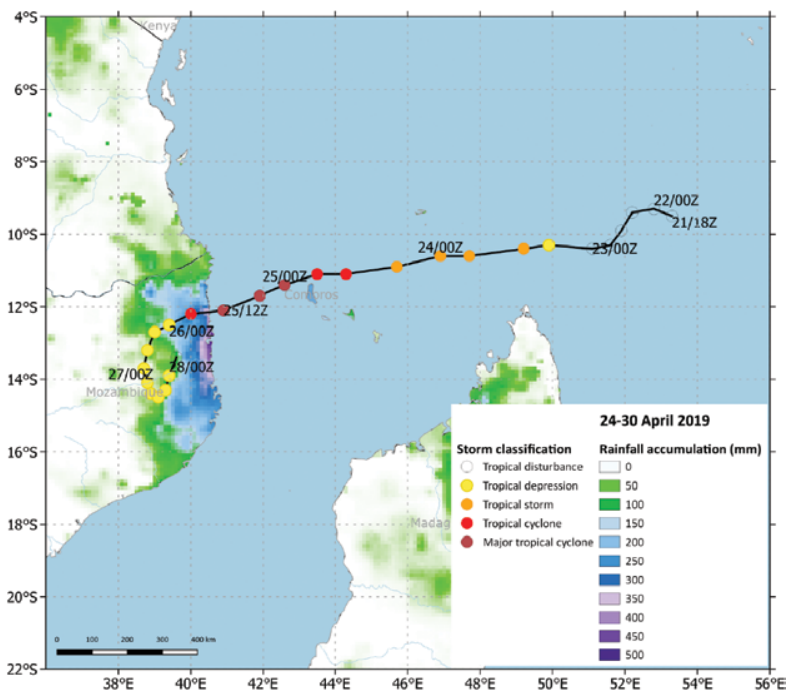

Cyclones Idai and Kenneth made landfall over the southeastern African country of Mozambique in March and April 2019, respectively. This was the first time since at least 1979 that two intense (Category 2 and Category 4) tropical cyclones made landfall over the country in a single season. Idai (4-16 March), the longest-lived tropical system on record in the Mozambique Channel, resulted in total damages of at least $\$ 2.2$ billion (U.S. dollars), and was the costliest and deadliest storm on record for the South Indian Ocean basin, with over 1200 fatalities across Mozambique, Zimbabwe, Malawi, and Madagascar. Kenneth (23-26 April) became the strongest storm on record to make landfall in Mozambique. (Figs. SB7.5 and 7.6 in State of the Climate in 2019; see discussion there in Sidebar 7.3)

Europe. In Europe, 2019 was among its four warmest years on record, with all four of the warmest years occurring since 2014. Many countries across the continent observed record or near-record warmth for the year. Record warmth was reported for Estonia (tied with 2015), Serbia, Belarus, Romania, the Ukraine, Moldova, Poland, Latvia, Lithuania, and Hungary.

A strong positive phase of the North Atlantic Oscillation contributed to extreme warmth in February, with many countries exceeding their normal monthly temperature by more than $2^{\circ} \mathrm{C}$. More than half of France's 150 measurement stations broke maximum monthly temperature records. In Latvia, a new winter maximum temperature record of $13.4^{\circ} \mathrm{C}$ was set on 16 February in Kolka. On 26 February, the United Kingdom (Kew Gardens) and Belgium (Uccle) each observed a temperature above $20^{\circ} \mathrm{C}$ in winter for the first time.

In May, temperatures from Italy to the Nordic countries were $2^{\circ}$ to $3^{\circ} \mathrm{C}$ below average in many regions, but the warmth returned with a vengeance. Two major heat waves occurred in June and July across central and western Europe. High temperature records were broken for daily maxima, daily minima, and daily averages. New June records were set at more than half of the 269 stations in Austria. In Italy, some locations set new records for their highest June minimum temperature. Milan, for example, only dipped down to $27.5^{\circ} \mathrm{C}$ on 27 June. On 25 July, a new German national daily high temperature record of $42.6^{\circ} \mathrm{C}$ was set at Lingen. New national all-time daily record temperatures were also set in the Netherlands, Belgium, Luxembourg, France, and England, as daily temperatures surpassed $40^{\circ} \mathrm{C}$ for the first time in Belgium and the Netherlands. The following day, the highest temperature ever recorded north of the Arctic Circle in Sweden $\left(34.8^{\circ} \mathrm{C}\right)$ was observed in the town of Markusvinsa.

The extreme summer heat waves along with dry conditions in the spring helped push most of Europe into extreme drought during 2019, with the most intense conditions across northern Germany and Poland. Major economic losses were incurred due to crop failure and low water levels of several major rivers that hindered navigation.

Asia. A low-pressure system over southwest Japan brought an unusually cool summer to a vast region of East Asia and expanded from central China to Japan. The average JuneJuly near-surface temperature over the region was among the three lowest in the past 20 years. However, even with this cool period, 2019 was the warmest year on record for Japan, Hong Kong, and Singapore (tied with 2016). Four of the past five years are among Singapore's 10 warmest on record. South Korea had its second-warmest year and China its fifth. The annual mean temperature across most of Vietnam was $1^{\circ}$ to $2^{\circ} \mathrm{C}$ above normal. On 20 April, the temperature in Huong Khe (Ha Tinh) reached $43.4^{\circ} \mathrm{C}$, a new national high temperature record for Vietnam. In southwest Asia, Tehran, Iran, set a new record high minimum (nighttime) summer 
temperature of $33.8^{\circ} \mathrm{C}$ on $17 \mathrm{July}$, surpassing its previous record by $1.2^{\circ} \mathrm{C}$.

Indonesia was marked by severe drought during the year. Usually, such dry spells are associated with El Niño years, but this was not the case in 2019. In one of the most affected areas, no rain fell in the East Sumba District of the East Nusa Tenggara Province for 263 days. In the northern Asian region of Siberia, many fires burned farther north than usual from June to August, which led to a new record of $27 \mathrm{Tg}\left(10^{12} \mathrm{~g}\right)$ of carbon for fire emissions from the Arctic. The emissions have increased every year since 2015 and were more than twice as high in 2019 than in any preceding year.

The summer monsoon season set in over Kerala in southern peninsular India on 8 June, seven days later than its climatological normal date. The monsoon covered the entire country on 19 July, four days later than its climatological normal date. Even with the late start and suppressed monsoon in June, India experienced one of its heaviest summer monsoon rains since 1995.

Five tropical cyclones made landfall in China. Tropical Cyclone Lekima was the fifth-strongest storm to make landfall since 1949. Seventy-four people perished or were missing, with approximately $\$ 8.5$ billion (U.S. dollars) of direct economic losses. Seven typhoons affected South Korea during the season, tying with 1950 and 1959 for the most on record. In the South China Sea, six tropical cyclones hit Vietnam directly.

Oceania. In 2019, about twice as many locations across Micronesia observed above-average annual mean temperatures as those that experienced below. Dry conditions were also present over much of the region during the first half of the year, which is typical during a weakening El Niño.

Near-normal temperatures prevailed across much of the southwest Pacific. In February, Tropical Cyclone Oma brought heavy rain, floods, and strong winds to the northern provinces of Vanuatu and Ile Art, the northern archipelago of New Caledonia. Both areas suffered substantial impacts to their agricultural industries. At the end of December, Tropical Cyclone Sarai impacted the main Fiji Island, Viti Levu, resulting in flooding and extensive damage to infrastructure.

The year was record hot and record dry in Australia. Warmth was widespread and persistent through the yearJanuary was Australia's warmest month on record for any time of the year. The end of the year saw more record-breaking heat. The country observed its all-time hottest day on 18 December, when the national maximum temperature reached $41.88^{\circ} \mathrm{C}$, easily exceeding the previous record of $40.30^{\circ} \mathrm{C}$ set on 7 January 2013. Six other days in December also exceeded this previous record. The annual mean temperature broke the previous record of 2013 by $0.29^{\circ} \mathrm{C}$. The

\section{Record and near-record high McArthur Forest Fire Danger Index across Australia}

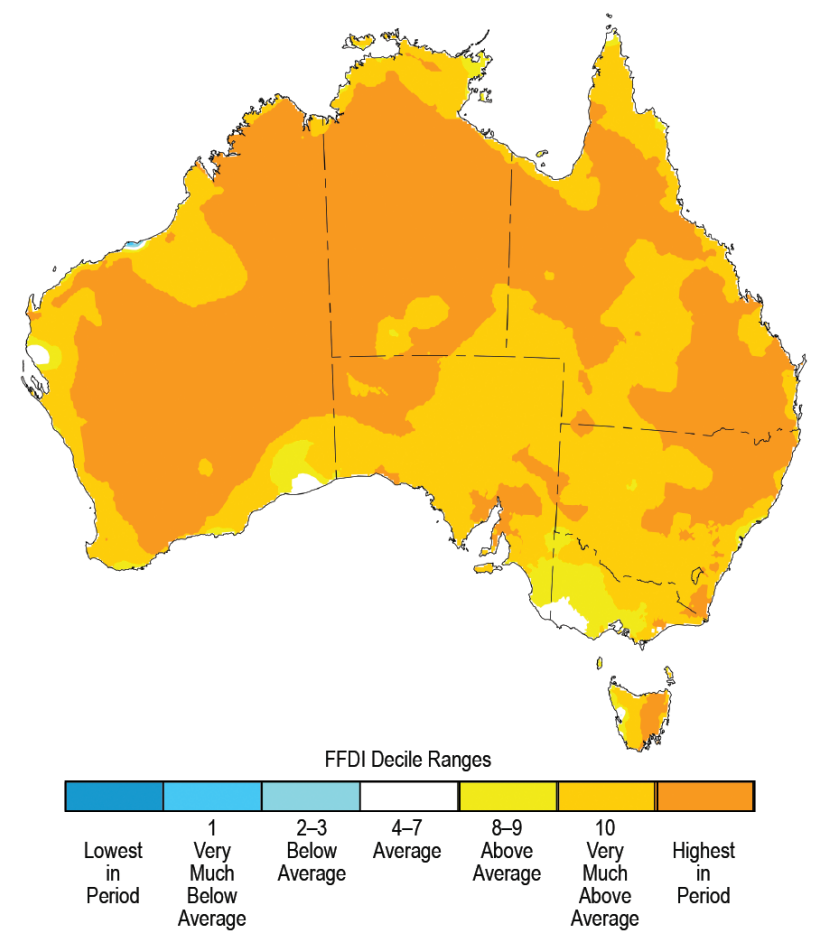

The McArthur Forest Fire Danger Index-a measure of fire weather severity-rose early in September and by December was the highest on record for Australia. Very large bushfires affected eastern Australia during this period, burning around 5 million hectares. Intense summer heat contributed to the dangerous fires in the southeast at the end of the year that lasted into the first days of 2020. Smoke from these wildfires was detected across much of the Southern Hemisphere. (Fig. SB7.14 in State of the Climate in 2019; see discussion there in Sidebar 7.6)

annual maximum temperature was $1.71^{\circ} \mathrm{C}$ above average, breaking that record, also set in 2013 , by $0.50^{\circ} \mathrm{C}$.

A very strong positive phase of the Indian Ocean dipole contributed to very low rainfall across Australia. Averaged across Australia, rainfall for 2019 was $277.6 \mathrm{~mm}$, well below the previous record low of $314.5 \mathrm{~mm}$ set in 1902. November and December were each record dry for their respective months. A negative phase of the Southern Annular Mode from late October to late December amplified the drying effect of the positive Indian Ocean dipole in eastern Australia.

New Zealand observed its fourth-warmest year on record. Widespread heat wave conditions brought the warmest January day on record to several locations. Also early in the year, dry conditions in the Tasman District fueled a large fire that burned for most of February and early March, and reportedly led to the largest aerial firefight in New Zealand's history. The cost of the event was nearly $\$ 2.5$ million (U.S. dollars). 


\section{AMS BOOKS}

The Ozone Layer:

From Discovery to Recovery

\section{Guy P. Brasseur}

From the discovery of ozone in the eighteenth century, through the late twentieth century international agreements to protect humanity from the destruction of ozone in the stratosphere, Guy P. Brasseur traces the evolution of our scientific knowledge on air quality issues and stratospheric chemistry and dynamics.

This first complete study of ozone research demonstrates the key role fundamental research plays in solving global environmental, climate, and human health problems...and, more importantly, shows that the scientific method works.

Meanwhile, convincing decision makers of research results that do not correspond to their values, or to the interests of business groups, stands as the highest hurdle in using science to benefit society.

Guy P. Brasseur is a distinguished scholar and director of the Atmospheric Chemistry

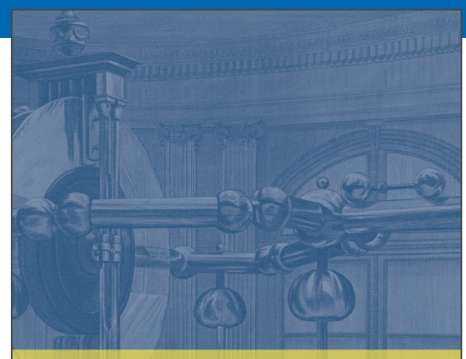

The Ozone Layer FROM DISCOVERY TO RECOVERY Guy P. Brasseur

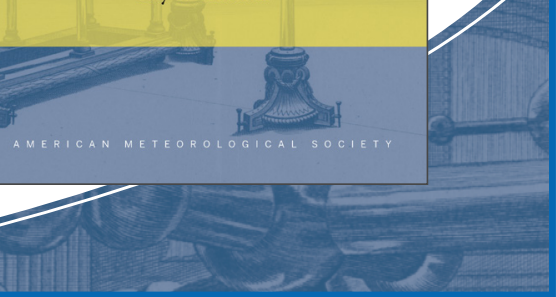

\section{Meteorological Monographs}

\section{A Century of Progress in Atmospheric and Related Sciences:} Celebrating the American Meteorological Society Centennial

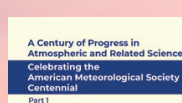

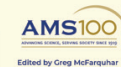

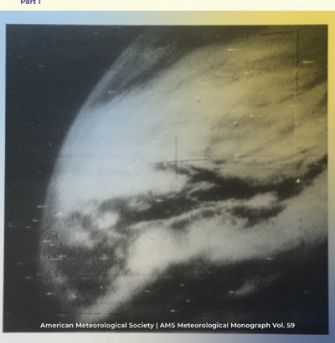

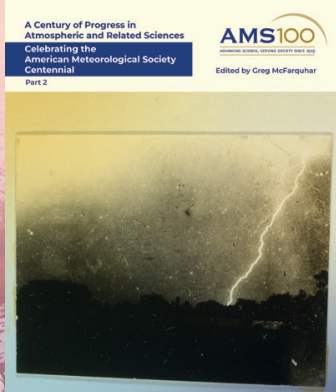

Twenty-seven articles, reviewing advances in key research topics and their grand challenges in the coming decades.

Fully open access and freely available online. Print edition available from The AMS Bookstore: bookstore.ainetsoc.org
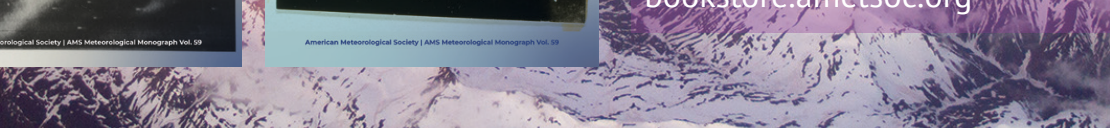